\title{
Diversity and genetic parameter of chili pepper (Capsicum annuum) based on yield component in three location
}

\author{
TRI WAHONO DYAH AYU SAYEKTI ${ }^{1, \bullet}$, MUHAMAD SYUKUR ${ }^{2, » \downarrow}$, SRI HENDRASTUTI HIDAYAT ${ }^{3}$, \\ AWANG MAHARIJAYA ${ }^{2}$ \\ ${ }^{1}$ Plant Breeding and Biotechnology Graduate Program, Department of Agronomy and Horticulture, Faculty of Agriculture, Institut Pertanian Bogor. Jl. \\ Meranti, Kampus IPB Darmaga, Bogor 16680, West Java, Indonesia. Tel.: +62-251-8629354, Fax.: +62-251-8629352, "email: dyah_sayekti@apps.ipb.ac.id \\ ${ }^{2}$ Department of Agronomy and Horticulture, Faculty of Agriculture, Institut Pertanian Bogor. J1. Meranti, Kampus IPB Darmaga, Bogor 16680, West \\ Java, Indonesia. Tel.: +62-251-8629354, Fax.: +62-251-8629352, “"email: muhsyukur@apps.ipb.ac.id \\ ${ }^{3}$ Department of Plant Protection, Faculty of Agriculture, Institut Pertanian Bogor. Jl. Meranti, Kampus IPB Darmaga, Bogor 16680, West Java, Indonesia
}

Manuscript received: 9 December 2020. Revision accepted: 16 January 2021.

\begin{abstract}
Sayekti TWDA, Syukur M, Hidayat SH, Maharijaya A. 2021. Diversity and genetic parameter of chili pepper (Capsicum annuum) based on yield component in three locations. Biodiversitas 22: 823-829. With the increase in the use of chili, it is necessary to develop these commodities through plant breeding activities. Phenotypes are not only determined by genetics, but also by environmental factors and the GxE interactions, so all the factors need to be considered. The aims of this study were to evaluate the variability of ten elite breeding lines and three commercial varieties of chili pepper (Capsicum annuum L.) across three different environments. This experiment was conducted in three environments namely Bogor, Kolaka, and Palembang, from January until July 2019. Thirteen genotypes consisting of ten elite lines and three commercial chili pepper were used. This experiment was arranged in a randomized complete block design (RCBD) with three replications for each environment. To determine the effect of environment, Combined Analysis of Variance was carried out for all environments using PBSTAT-GE. The environment used in this experiment was lowland that varies between each other. The genotype with the fastest harvesting age relative in three environments was F7-145293-19-8-3-1131. The highest number of fruits per plant was observed in genotype F9-160291-9-4-3-2-1-1-1 with 261 fruits per plant. The highest yield was observed in genotype F7-145174-9-7-1-5-3. From the clustering analysis, this population was grouped into five clusters. The heritability values for the 12 observed traits ranged between $22.68-69.97 \%$, classified into high and moderate criteria.
\end{abstract}

Keywords: Chili pepper, cluster analysis, genetic parameter, heritability, yield components

\section{INTRODUCTION}

Since the demand for chili for consumption and industrial purposes is increasing, chili research becoming important as well. Among several types of chili pepper that are commonly consumed, such as sweet pepper and chili pepper, the most commonly consumed fresh is the chili pepper. The increase in the use of chili for fresh consumption reaches $10.87 \%$ each year. Total use of chili pepper reaching 1,925 million tons per year. In order to provide people's needs for chilies, it is necessary to develop these commodities through plant breeding activities. The objectives of plant breeding include improving the quantity and quality of yields, post-harvest resistance, pest and disease resistance, and tolerance to abiotic stress in suboptimal environments (Wattimena 2011). Plant breeding activities are important to assemble new high-yielding varieties that potential to produce biomass and distribute it to the harvested part (Syukur et al. 2015). According to Syukur et al. (2010), the potential productivity of chili pepper (Capsicum annuum L.) in Indonesia can reach more than 20 tons $\mathrm{ha}^{-1}$. The use of elite lines was an important step in determining the amount of production at harvest time (Nsabiyera et al. 2012).

To get the genotype that well growing and has a potential yield, the breeder needs to consider the genetic potential of the genotype to be developed. Besides genetic potential, the environment also needs to be considered because the phenotype of the plant not only determined by genetics, but also by environmental factors and the interaction between genetic and environmental (Roy 2000). This interaction makes breeding activities more complicated. If the interaction of Genetic x Environment (GXE) was not significant, all genotypes can perform stably in each environment (Cabral et al. 2017). However, if this GXE interaction was significant, then there will be differences in plant performance in certain environments (Hu et al. 2013) thus making it difficult for breeders to provide suitable genotype recommendations. It is necessary to study this phenomenon so that it can be used as a basis to recommend the genotypes that are suitable for each environment on purpose to increase productivity. The development of site-specific superior genotypes can be directed to obtain environment-specific varieties, while varieties that are superior in all environments can be released into varieties that are widely adapted (Ganefianti et al. 2009).

From the previous study, some elite lines or genotypes of chili pepper with a high yield potential have been found. These lines are expected to be widely used for consumption and industrial purpose. To get these purposes, it necessary to study the performance of each line at various locations, 
as well as to see the effect of factors on the yield component. The objective of this experiment is to evaluate the character variability of ten elite lines and three commercial varieties of chili pepper in three different environments.

\section{MATERIALS AND METHODS}

\section{Study area and genetic material}

This experiment was conducted in three environments. First set (set one) was conducted at Tajur PKHT-LPPM IPB University Experimental Field (250 m asl), Bogor, West Java, Indonesia. Second set (set two) at Universitas Sembilan Belas November Kolaka Experimental Field (38 $\mathrm{m}$ asl), Kolaka, Southeast Sulawesi. Third set (set three) was conducted at Universitas IBA (8 $\mathrm{m}$ asl.), Palembang, South Sumatra.

Thirteen genotypes consisting of ten elite lines and three commercial chili pepper were used. This experiment was arranged in a randomized complete block design (RCBD) with three replications for each set. The plot that used was a soil bed with $6 \mathrm{~m} \times 1 \mathrm{~m}$ soil in size.

\section{Procedures}

Seed of thirteen genotypes of chili pepper was sown in the seedling tray for 5 weeks, then transplanted on the soil beds with a spacing $50 \mathrm{~cm}$ x $50 \mathrm{~cm}$ (24 plants per plot). The seedling that transplanted was a well-growth seedling with green leaves and not affected by pest or disease. The soil beds were covered by black-silver plastic mulch. Watering is done every day to ensure that plants are not affected by drought. Fertilizer was applied every week since seedling phase using NPK (16-16-16) (250 mL per plant) and foliar fertilizer. The concentration of fertilizer that used was $10 \mathrm{~g} \mathrm{~L}^{-1}$ for NPK 16-16-16 and $5 \mathrm{~g} \mathrm{~L}^{-1}$ for foliar fertilizer. Pest and disease management were done using recommended pesticide when needed. Weeding was scheduled for every two weeks after transplanting. Harvesting was done when $75 \%$ of plant population already has ripe fruit. The ripe fruit marked by $80 \%$ of the fruit has been red. Harvesting was scheduled every week for eight weeks.

Table 1. F-Ratios used to test effects for randomized complete blocks experiments combined over location

\begin{tabular}{lcc}
\hline Sources of variation & $\begin{array}{c}\text { Mean } \\
\text { square }\end{array}$ & $\begin{array}{c}\text { Expected mean squares } \\
\text { (fixed model) }\end{array}$ \\
\hline Location $(\mathrm{l})$ & M1 & $\sigma^{2} \mathrm{e}+\mathrm{t} \sigma^{2} \mathrm{R}(\mathrm{L})+\mathrm{rt} \sigma^{2} \mathrm{~L}$ \\
Block (Location) $(\mathrm{r})$ & $\mathrm{M} 2$ & $\sigma^{2} \mathrm{e}+\mathrm{t} \sigma^{2} \mathrm{R}(\mathrm{L})$ \\
Treatment $(\mathrm{T})$ & $\mathrm{M} 3$ & $\sigma^{2} \mathrm{e}+\mathrm{rl} \sigma^{2} \mathrm{~T}$ \\
Location $x$ treatment & M4 & $\sigma^{2} \mathrm{e}+\mathrm{r} \sigma^{2} \mathrm{TL}$ \\
Pooler error & M5 & $\sigma^{2} \mathrm{e}$ \\
\hline
\end{tabular}

Note: $\sigma^{2} \mathrm{e}$ : environment variance; $\sigma^{2} \mathrm{TL}$ : location $\mathrm{x}$ treatment variance; $\sigma^{2} \mathrm{~T}$ : treatment variance; $\sigma^{2} \mathrm{~L}$ : location variance; $\sigma^{2} \mathrm{R}(\mathrm{L})$ : block variance
Observations were made on yield and non-yield components based on IPGRI parameters (1995). The nonyield component parameters comprised of plant height, stem diameter, leaf length width, days to flowering, and days to harvest. The yield component parameters consist of fruit length and width, fruit weight, number of fruits per plant, and fruit yield per plant.

\section{Data analysis}

To determine the effect of environment, Combined Analysis of Variance (Combined ANOVA) was carried out for all environments using PBSTAT-GE. Genetic parameters (variance and heritability) and interaction of genotypes-by-environment $\left(\mathrm{G}^{*} \mathrm{E}\right)$ were estimated using fixed models by the following method (McIntosh 1983):

$$
\begin{aligned}
& \sigma^{2}{ }_{\mathrm{G}}=(\mathrm{M} 3-\mathrm{M} 5) / \mathrm{rl} \\
& \sigma_{\mathrm{GXE}}^{2}=(\mathrm{M} 4-\mathrm{M} 5) / \mathrm{r} \\
& \sigma^{2} \mathrm{e}=\mathrm{M} 5 \\
& \sigma_{\mathrm{P}}^{2}=\sigma_{\mathrm{G}}^{2}+\left(\sigma_{\mathrm{GXE}}^{2} / \mathrm{l}\right)+\left(\sigma^{2} \mathrm{e} / \mathrm{rl}\right) \\
& \mathrm{h}^{2} \mathrm{bs}=\left(\sigma_{\mathrm{G}}^{2} / \sigma_{\mathrm{P}}^{2}\right) \times 100 \%
\end{aligned}
$$

\section{RESULTS AND DISCUSSION}

\section{Variability of 13 chili pepper}

The coefficient of variation (C.V) of this experiment was less than $20 \%$ for almost all characters indicating the precision in the data recorded. From the result of Combined Analysis of Variance, it can be seen that genotype, environment, and the GxE interaction have a significant effect in the observed characters. This result indicates that the productivity of chili pepper was affected by genotype, environment, and their interactions. Environment, in this study, was the biggest contributor to yield variability, then the genotype and GxE interaction effect (Table 2). These cases indicate that the response to crop yield depends on the environmental conditions.

Days to harvest ranged from 67-95 days after planting (DAP) in Bogor, 69-92 DAP in Kolaka, and 83-94 DAP in Palembang (Table 3). The genotype with the fastest harvesting age in Bogor was F7-145293-19-8-3-113-1 (67 DAP) and this genotype tends to reach harvest early at all three locations. Whereas at Kolaka and Palembang locations, genotypes F9-145291-115-8-1-1-1, F7-14529110-7-1-1-1-2, and other genotypes had an early harvest age; however, were not significantly different from each other.

The yield components comprised of fruit length, fruit weight, number of fruits per plant, and yield per plant. Genotype F7-160291-4-13-9-8-1 displayed the best fruit length across all environments, which had $5.30 \mathrm{~cm}$ fruit length (Table 4), and significant differences were observed for fruit length across environments. The Chili pepper grown in Bogor was significantly longer than in other environments and environmental and climate factors may have caused this. Different results were obtained for fruit weight and significant differences between environments were also observed but chilies are grown in Bogor conversely had a lower weight than other environments. Highest fruit weight was observed in Bara with an average fruit weight of $2.20 \mathrm{~g}$ per fruit (Table 5). 
Table 2. Estimation of mean square for different characters of 13 chili pepper under combined analysis of variance

\begin{tabular}{|c|c|c|c|c|c|c|c|c|}
\hline \multirow[b]{2}{*}{ Source } & \multirow[b]{2}{*}{ df } & \multicolumn{7}{|c|}{ Mean square } \\
\hline & & Fruit length & $\begin{array}{c}\text { Fruit } \\
\text { diameter }\end{array}$ & Fruit weight & $\begin{array}{c}\text { Number of fruits } \\
\text { per plant }\end{array}$ & $\begin{array}{l}\text { Fruit yield } \\
\text { per plant }\end{array}$ & $\begin{array}{l}\text { Days to } \\
\text { flowering }\end{array}$ & $\begin{array}{l}\text { Days to } \\
\text { harvest }\end{array}$ \\
\hline Environment & 2 & $12.423^{* *}$ & $0.781^{* *}$ & $0.813^{* *}$ & $307160.2^{* *}$ & $40981.0^{* *}$ & $1701.13^{* *}$ & $2101.64^{* * *}$ \\
\hline Rep(Env) & 6 & $0.036^{\mathrm{ns}}$ & $0.011^{\mathrm{ns}}$ & $0.009^{\text {ns }}$ & $456.6^{\mathrm{ns}}$ & $3362.0^{* * *}$ & $9.77^{* *}$ & $51.35^{* 8}$ \\
\hline Genotype & 12 & $1.726^{* * *}$ & $0.094^{* *}$ & $1.183^{* *}$ & $11829.7^{* *}$ & $21636.0^{* * *}$ & $24.09^{\text {ns }}$ & $127.09^{\mathrm{ns}}$ \\
\hline GxE & 24 & $0.893^{* * *}$ & $0.036^{* *}$ & $0.499^{* *}$ & $23885.5^{* *}$ & $21709.0^{* * *}$ & $16.13^{* *}$ & $152.82^{* *}$ \\
\hline Error & 72 & $0.063^{* * *}$ & $0.063^{* *}$ & $0.019^{* * *}$ & $400.6^{* *}$ & $712.9^{\text {ns }}$ & $3.48^{88}$ & $17.08^{88}$ \\
\hline CV (\%) & & 5.84 & 10.46 & 8.70 & 11.61 & 11.00 & 5.43 & 5.02 \\
\hline
\end{tabular}

Note: CV: Coefficient of Variance; Rep: Replication; Env: Environment; GXE: Genotype x Environment; ** significant at level of 1\%;

* significant at level 5\%; ns: not significant

Table 3. Days to Harvest of 13 chili pepper genotypes across different locations

\begin{tabular}{|c|c|c|c|c|}
\hline \multirow{2}{*}{ Genotype } & Bogor & Kolaka & Palembang & \multirow{2}{*}{ Mean } \\
\hline & \multicolumn{3}{|c|}{--------Days to Harvest (DAP)--------. } & \\
\hline F7-145291-10-7-1-1-1-2 & $74.00 \mathrm{e}$ & $70.77 \mathrm{ef}$ & $96.33 a$ & 80.37 \\
\hline F9-160291-9-4-3-2-1-1-1 & $95.00 \mathrm{a}$ & $69.97 \mathrm{f}$ & $88.67 \mathrm{abc}$ & 84.54 \\
\hline F9-160291-3-12-5-4-5-1-1 & $88.00 \mathrm{~b}$ & 73.13def & $98.33 \mathrm{a}$ & 86.49 \\
\hline F9-145291-115-8-1-1-1 & $88.00 \mathrm{~b}$ & $69.93 \mathrm{f}$ & $87.00 \mathrm{abc}$ & 81.64 \\
\hline F9-160291-3-12-5-51-1-1-2 & $74.33 \mathrm{~d}$ & 73.70def & $96.33 \mathrm{a}$ & 81.46 \\
\hline F8-145291-14-10-10-4-9-1 & $81.00 \mathrm{c}$ & $81.50 \mathrm{bc}$ & $98.33 \mathrm{a}$ & 86.94 \\
\hline F7-145291-14-9-3-12-1 & $74.00 \mathrm{e}$ & $73.27 \mathrm{def}$ & $81.00 \mathrm{c}$ & 76.09 \\
\hline F7-160291-4-13-9-8-1 & $74.00 \mathrm{e}$ & $76.43 \mathrm{cde}$ & $94.33 \mathrm{ab}$ & 81.59 \\
\hline F7-145174-9-7-1-5-3 & $74.00 \mathrm{e}$ & $83.60 \mathrm{~b}$ & $96.33 \mathrm{a}$ & 84.64 \\
\hline F7-145293-19-8-3-113-1 & $67.00 \mathrm{f}$ & $77.53 \mathrm{~cd}$ & $83.00 \mathrm{bc}$ & 75.84 \\
\hline Bara & $81.00 \mathrm{c}$ & $76.46 \mathrm{cde}$ & $90.67 \mathrm{abc}$ & 82.71 \\
\hline Batari & $81.00 \mathrm{c}$ & $74.97 \mathrm{def}$ & $83.00 \mathrm{bc}$ & 79.66 \\
\hline Genie & $88.00 \mathrm{~b}$ & $91.49 \mathrm{a}$ & $83.00 \mathrm{bc}$ & 87.50 \\
\hline Mean & $79.95 \mathrm{~b}$ & $76.37 \mathrm{C}$ & $90.49 \mathrm{~A}$ & \\
\hline
\end{tabular}

Note: Number followed by the same letter in the same column were not significantly different to DMRT 5\% level; Number followed by the same capital letter in the same row were not significantly different to HSD 5\% level

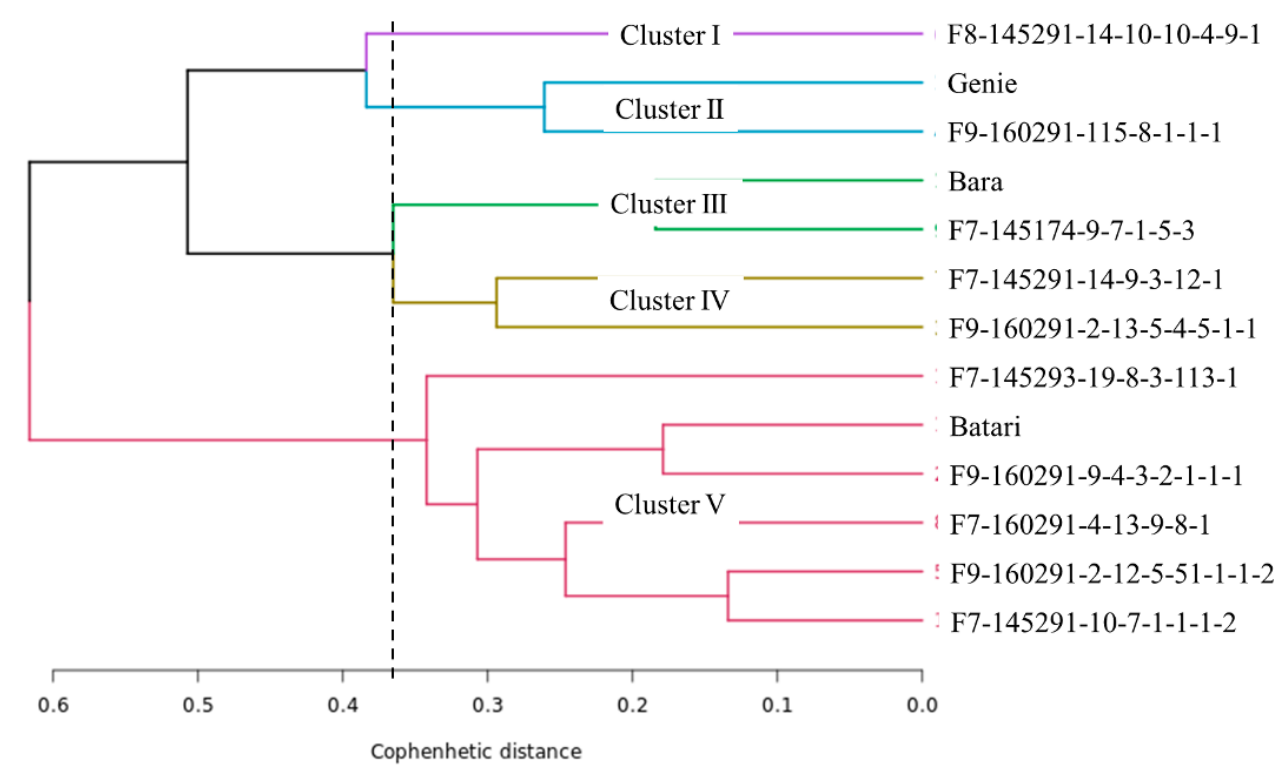

Figure 1. Dendrogram generated by hierarchical cluster analysis showing the relationships among the characterized chili pepper genotypes using 12 quantitative traits 
For the number of fruits per plant, the results indicated that there was a large variation between locations (Table 6). Some genotypes have an increase or decrease in the number of fruits per plant when grown in different environments. However, several genotypes were observed to be quite stable across three environments, namely Bara with a difference of $32.58 \%$ in the number of fruits per plant. Meanwhile, the genotype with the highest number of fruits per plant was F9-160291-9-4-3-2-1-1-1 with 261 fruits per plant. But in general, these genotypes did not have stable fruit counts per plant in all environments. In general, the genotypes grown in Bogor had a higher number of fruits per plant compared to other environments. Similar results were observed for the yield per plant and F7-145174-9-7-1-5-3 was seen to have highest yield per plant. The yield of evaluated genotype was quite stable in two of the three environments with an average value of $311.80 \mathrm{~g}$ fruit per plant.

The genotypes were grouped into two major clusters and several sub-clusters (Figure 1). Partitioning clusters at a similarity coefficient of 0.62 for ease of interpretation generated five different clusters. Cluster I contained six genotypes, including five elite lines and one commercial variety (Batari), with similarity coefficient ranging from 0.637-0.866 (Dissimilarity ranging from 0.134-0.363). Cluster II consisted of two genotypes namely F9-160291-312-5-4-5-1-1 and F7-145291-14-9-3-12-1 with coefficient of similarity of 0.71 . Cluster III contained two genotypes namely Bara and F7-145174-9-7-1-5-3 with coefficient of similarity of 0.82 . The fourth cluster consisted of two genotypes, Genie and F9-145291-115-8-1-1-1 with coefficient of similarity of 0.74 , and the fifth cluster consisted of single genotype F8-145291-14-10-10-4-9-1.

Table 4. Mean fruit length of 13 genotypes of chili pepper evaluated across different environments

\begin{tabular}{lllll}
\hline \multicolumn{1}{c}{ Genotype } & Bogor & Kolaka & Palembang & \multirow{2}{*}{ Mean } \\
\cline { 2 - 4 } & & --------Fruit length (cm)-------- & $3.99 \mathrm{f}$ \\
F7-145291-10-7-1-1-1-2 & $4.85 \mathrm{~d}$ & $3.84 \mathrm{efgh}$ & $3.28 \mathrm{~d}$ & $3.91 \mathrm{fg}$ \\
F9-160291-9-4-3-2-1-1-1 & $4.88 \mathrm{~d}$ & $3.50 \mathrm{~h}$ & $3.33 \mathrm{~d}$ & $4.64 \mathrm{bc}$ \\
F9-160291-3-12-5-4-5-1-1 & $6.80 \mathrm{a}$ & $3.85 \mathrm{efgh}$ & $3.28 \mathrm{~d}$ & $4.67 \mathrm{~b}$ \\
F9-145291-115-8-1-1-1 & $5.17 \mathrm{~cd}$ & $4.60 \mathrm{c}$ & $4.25 \mathrm{~b}$ & $4.27 \mathrm{ed}$ \\
F9-160291-3-12-5-51-1-1-2 & $4.90 \mathrm{~d}$ & $4.14 \mathrm{de}$ & $3.79 \mathrm{bcd}$ & $4.09 \mathrm{ef}$ \\
F8-145291-14-10-10-4-9-1 & $5.12 \mathrm{~cd}$ & $3.77 \mathrm{fgh}$ & $3.39 \mathrm{~d}$ & $4.70 \mathrm{~b}$ \\
F7-145291-14-9-3-12-1 & $5.35 \mathrm{bc}$ & $4.68 \mathrm{c}$ & $4.06 \mathrm{bc}$ & $5.30 \mathrm{a}$ \\
F7-160291-4-13-9-8-1 & $5.66 \mathrm{~b}$ & $5.44 \mathrm{a}$ & $4.80 \mathrm{a}$ & $4.41 \mathrm{~cd}$ \\
F7-145174-9-7-1-5-3 & $4.80 \mathrm{~d}$ & $4.21 \mathrm{~d}$ & $4.22 \mathrm{~b}$ & $3.71 \mathrm{~g}$ \\
F7-145293-19-8-3-113-1 & $4.10 \mathrm{e}$ & $3.56 \mathrm{gh}$ & $3.48 \mathrm{~cd}$ & $3.69 \mathrm{bcd}$ \\
Bara & $4.08 \mathrm{e}$ & $5.07 \mathrm{~b}$ & $3.74 \mathrm{bcd}$ & $3.28 \mathrm{ed}$ \\
Batari & $4.02 \mathrm{e}$ & $4.01 \mathrm{def}$ & $4.04 \mathrm{bc}$ & $3.92 \mathrm{fg}$ \\
Genie & $4.09 \mathrm{e}$ & $3.89 \mathrm{defg}$ & $3.79 \mathrm{C}$ & $4.01 \mathrm{f}$ \\
Mean & $4.91 \mathrm{~A}$ & $4.19 \mathrm{~B}$ & \\
\hline
\end{tabular}

Note: Number followed by the same letter in the same column were not significantly different to DMRT 5\% level; Number followed by the same capital letter in the same row were not significantly different to HSD 5\% level

Table 5. Fruit weight of 13 genotypes of chili pepper in different location

\begin{tabular}{|c|c|c|c|c|}
\hline \multirow{2}{*}{ Genotype } & Bogor & Kolaka & Palembang & \multirow{2}{*}{ Mean } \\
\hline & \multicolumn{3}{|c|}{---------Fruit weight (g)--------- } & \\
\hline F7-145291-10-7-1-1-1-2 & $1.47 \mathrm{c}$ & $1.30 \mathrm{gh}$ & $1.25 \mathrm{fg}$ & $1.34 \mathrm{fg}$ \\
\hline F9-160291-9-4-3-2-1-1-1 & $1.29 \mathrm{cde}$ & $1.13 \mathrm{~h}$ & $1.13 \mathrm{~g}$ & $1.18 \mathrm{~h}$ \\
\hline F9-160291-3-12-5-4-5-1-1 & $2.75 \mathrm{a}$ & $1.59 \mathrm{ef}$ & $1.67 \mathrm{cde}$ & $1.99 \mathrm{bc}$ \\
\hline F9-145291-115-8-1-1-1 & $1.75 b$ & $1.94 \mathrm{~cd}$ & $1.95 \mathrm{c}$ & $1.88 \mathrm{~cd}$ \\
\hline F9-160291-3-12-5-51-1-1-2 & $1.28 \mathrm{de}$ & $1.29 \mathrm{gh}$ & $1.27 \mathrm{fg}$ & $1.28 \mathrm{gh}$ \\
\hline F8-145291-14-10-10-4-9-1 & $1.39 \mathrm{~cd}$ & $1.50 \mathrm{fg}$ & $1.45 \mathrm{ef}$ & $1.45 \mathrm{ef}$ \\
\hline F7-145291-14-9-3-12-1 & $1.74 \mathrm{~b}$ & $1.79 \mathrm{de}$ & $1.76 \mathrm{~cd}$ & $1.76 \mathrm{~d}$ \\
\hline F7-160291-4-13-9-8-1 & $1.04 \mathrm{f}$ & $1.69 \mathrm{def}$ & $1.75 \mathrm{~cd}$ & $1.49 \mathrm{e}$ \\
\hline F7-145174-9-7-1-5-3 & $1.37 \mathrm{~cd}$ & $2.30 \mathrm{~b}$ & $2.43 b$ & $2.03 b$ \\
\hline F7-145293-19-8-3-113-1 & $1.22 \mathrm{def}$ & $1.30 \mathrm{gh}$ & $1.30 \mathrm{fg}$ & $1.27 \mathrm{~h}$ \\
\hline Bara & $1.12 \mathrm{ef}$ & $2.91 \mathrm{a}$ & $2.85 \mathrm{a}$ & $2.20 \mathrm{a}$ \\
\hline Batari & $1.09 \mathrm{f}$ & $1.23 \mathrm{gh}$ & $1.30 \mathrm{fg}$ & $1.21 \mathrm{~h}$ \\
\hline Genie & $1.097 \mathrm{f}$ & 2.11 & $1.47 \mathrm{def}$ & $1.55 \mathrm{e}$ \\
\hline Mean & $1.43 \mathrm{~B}$ & $1.69 \mathrm{~A}$ & $1.66 \mathrm{~A}$ & \\
\hline
\end{tabular}

Note: Number followed by the same letter in the same column were not significantly different to DMRT 5\% level; Number followed by the same capital letter in the same row were not significantly different to HSD 5\% level 
The heritability values for the 12 observed traits ranged between 22.68-69.97\% and were classified into several criteria. The properties of plant height, leaf length, days to flowering, fruit length, fruit diameter, and fruit weight have high heritability. Whereas stem diameter, leaf width, days to harvest, number of fruits per plant, and fruit yield have moderate heritability. Criteria of heritability were determined based on Whirter (1979) as high (> 50\%), moderate $(20-50 \%)$, and low $(<20 \%)$ (Table 8$)$.

\section{Discussion}

The environment used in this experiment was lowland with elevations ranging between Palembang ( $8 \mathrm{~m}$ asl), Kolaka (38 m asl), and Bogor (250 m asl), and climatic conditions varied between these environments. Bogor has a temperature ranging from 25.97-27.05 ${ }^{\circ} \mathrm{C}$ with $86.5 \%$ humidity and rainfall varied from 297.10-679.60 mm per month. Kolaka temperature ranges from $26.9-28.60{ }^{\circ} \mathrm{C}$ with humidity of $83.45 \%$ and the rainfall ranging from 45.00 $263.9 \mathrm{~mm}$ per month. Palembang city temperature ranges from 27.01-28.28 ${ }^{\circ} \mathrm{C}$ with a humidity of $84.24 \%$ and rainfall ranging from $80.70-119.70 \mathrm{~mm}$ per month.

The harvest age of plants grown in Bogor was significantly shorter than those grown in Kolaka and Palembang (Table 3). According to (Pimenta et al 2016) environmental factors are known to greatly influence the expression of quantitative traits. However, in some cases, environmental factors affect the qualitative characters and harvesting age (Kandel et al. 2017). All quantitative traits were found to differ significantly among genotypes and also between environments. Variations in growth and yield components have been reported in many studies (Sharma et al. 2010; Thul et al. 2009). The yield per plant in Bogor was significantly higher than in Kolaka and Palembang. Although all the factors that cause this cannot be determined. However, this is thought to be related to the temperature, rainfall, and humidity of the location. Bogor has a relatively lower temperature, sufficient rainfall, while the Kolaka and Palembang locations tend to have high temperatures and humidity with low rainfall. High temperature and humidity accompanied by low rainfall have been negatively correlated to flowering and fruit sets (Wubs et al. 2011).

In this experiment, phenotypic relatedness was evident in cluster analysis, with two major clusters being formed for all genotypes evaluated. To see the grouping of these genotypes, clustering was carried out at a similarity level of 0.62 to produce 5 groups. This may probably have genotypes in the same species (C. annuum), so the base gene pool was narrow (Madu and Uguru 2006). This phenotypic relatedness also evidenced by the narrow range of similarity coefficient (0.637-0.866) (Votava et al. 2005).

One of the important information that needs to be known before carrying out further breeding and selection is related to the inheritance pattern of the targeted traits and the dominant factors that control these characters. This information can be found simply through the heritability value $\left(h^{2}\right)$ of the targeted trait. The heritability value itself is a comparison between the values of variety of genotypes and their respective phenotypes. This shows that the heritability value is an estimator of how big the role of genetics plays in the expression of observed phenotypic characters. High heritability value indicates that the trait is more influenced by genetic factors than environmental factors.

Table 6. Number of fruits per plant of 13 genotypes of chili pepper evaluated across different locations

\begin{tabular}{|c|c|c|c|c|}
\hline \multirow{2}{*}{ Genotype } & Bogor & Kolaka & Palembang & \multirow{2}{*}{ Mean } \\
\hline & \multicolumn{3}{|c|}{---------Number of fruit per plant--------- } & \\
\hline F7-145291-10-7-1-1-1-2 & $227.9 \mathrm{de}$ & $77.48 \mathrm{gha}$ & $85.39 \mathrm{ea}$ & $130.26 \mathrm{gh}$ \\
\hline F9-160291-9-4-3-2-1-1-1 & $652.70 \mathrm{a}$ & 67.36haa & $63.80 \mathrm{ea}$ & $261.29 \mathrm{a}$ \\
\hline F9-160291-3-12-5-4-5-1-1 & $208.57 \mathrm{e}$ & $94.80 \mathrm{efa}$ & $213.83 \mathrm{ab}$ & $172.40 \mathrm{cde}$ \\
\hline F9-145291-115-8-1-1-1 & $319.97 b$ & $115.91 \mathrm{cda}$ & $158.12 \mathrm{~cd}$ & $198.00 \mathrm{~b}$ \\
\hline F9-160291-3-12-5-51-1-1-2 & $294.67 b c$ & 76.90gha & $90.56 \mathrm{ea}$ & $154.04 \mathrm{ef}$ \\
\hline F8-145291-14-10-10-4-9-1 & $198.74 \mathrm{e}$ & $89.27 \mathrm{fga}$ & 65.97ea & $117.99 \mathrm{~h}$ \\
\hline F7-145291-14-9-3-12-1 & $206.87 \mathrm{e}$ & $106.81 \mathrm{dea}$ & $241.05 \mathrm{aa}$ & $184.91 \mathrm{bcd}$ \\
\hline F7-160291-4-13-9-8-1 & $201.17 \mathrm{e}$ & $100.92 \mathrm{def}$ & $153.24 \mathrm{~cd}$ & $151.77 \mathrm{ef}$ \\
\hline F7-145174-9-7-1-5-3 & $257.63 \mathrm{~cd}$ & 137.63baa & $180.20 \mathrm{bc}$ & $191.82 \mathrm{bc}$ \\
\hline F7-145293-19-8-3-113-1 & $284.63 b c$ & 77.70gha & 75.86ea & $146.06 \mathrm{fg}$ \\
\hline Bara & $199.23 \mathrm{e}$ & 174.07aaa & $134.31 \mathrm{da}$ & $169.21 \mathrm{de}$ \\
\hline Batari & $259.47 \mathrm{~cd}$ & $73.69 \mathrm{gha}$ & $248.30 \mathrm{aa}$ & $193.82 b$ \\
\hline Genie & 221.97de & $125.87 \mathrm{bca}$ & $155.75 \mathrm{~cd}$ & $167.86 \mathrm{de}$ \\
\hline Mean & $271.81 \mathrm{~A}$ & $101.42 \mathrm{C}$ & $143.57 \mathrm{~B}$ & \\
\hline
\end{tabular}

Note: Number followed by the same letter in the same column were not significantly different to DMRT 5\% level; Number followed by the same capital letter in the same row were not significantly different to HSD 5\% level 
Table 7. Fruit yield per plant of 13 chili peppers evaluated across different locations

\begin{tabular}{|c|c|c|c|c|}
\hline \multirow{2}{*}{ Genotype } & Bogor & Kolaka & Palembang & \multirow{2}{*}{ Mean } \\
\hline & \multicolumn{3}{|c|}{---------Yield per plant (g)--------- } & \\
\hline F7-145291-10-7-1-1-1-2 & $256.49 \mathrm{c}$ & $153.03 \mathrm{e}$ & $125.63 \mathrm{c}$ & $178.38 \mathrm{~h}$ \\
\hline F9-160291-9-4-3-2-1-1-1 & $378.60 \mathrm{a}$ & $197.13 \mathrm{~cd}$ & $71.48 \mathrm{~d}$ & $215.74 f g$ \\
\hline F9-160291-3-12-5-4-5-1-1 & $364.50 \mathrm{ab}$ & $233.87 \mathrm{ab}$ & $310.41 b$ & $302.92 \mathrm{ab}$ \\
\hline F9-145291-115-8-1-1-1 & $342.08 \mathrm{ab}$ & $225.97 \mathrm{abc}$ & $281.88 b$ & $283.31 b c$ \\
\hline F9-160291-3-12-5-51-1-1-2 & $314.76 b$ & $219.33 \mathrm{abc}$ & $123.77 \mathrm{c}$ & $219.29 f g$ \\
\hline F8-145291-14-10-10-4-9-1 & 210.82 cde & $206.87 \mathrm{bcd}$ & $101.43 \mathrm{~cd}$ & $173.04 \mathrm{~h}$ \\
\hline F7-145291-14-9-3-12-1 & $325.18 \mathrm{ab}$ & $208.80 \mathrm{bcd}$ & $400.36 \mathrm{a}$ & $311.45 \mathrm{a}$ \\
\hline F7-160291-4-13-9-8-1 & 201.01cde & $188.50 \mathrm{~d}$ & $258.72 b$ & $216.08 f g$ \\
\hline F7-145174-9-7-1-5-3 & $317.20 \mathrm{ab}$ & $186.44 d$ & $431.75 \mathrm{a}$ & $311.80 \mathrm{a}$ \\
\hline F7-145293-19-8-3-113-1 & $237.16 \mathrm{~cd}$ & $243.63 \mathrm{a}$ & $100.03 \mathrm{~cd}$ & $193.61 \mathrm{gh}$ \\
\hline Bara & $172.40 \mathrm{e}$ & $227.83 \mathrm{ab}$ & $391.12 \mathrm{a}$ & $263.78 \mathrm{~cd}$ \\
\hline Batari & $235.96 \mathrm{~cd}$ & $220.13 \mathrm{abc}$ & $304.97 b$ & $253.69 \mathrm{de}$ \\
\hline Genie & $192.37 \mathrm{de}$ & $198.73 \mathrm{~cd}$ & $303.80 \mathrm{~b}$ & $231.63 \mathrm{ef}$ \\
\hline Mean & $272.96 \mathrm{~A}$ & $208.48 \mathrm{C}$ & $246.56 \mathrm{~B}$ & \\
\hline
\end{tabular}

Note: Number followed by the same letter in the same column were not significantly different to DMRT 5\% level; Number followed by the same capital letter in the same row were not significantly different to HSD 5\% level

Table 8. Estimation of genetic parameters of 13 chili pepper genotype

\begin{tabular}{|c|c|c|c|c|c|c|}
\hline Character & $\sigma^{2} \mathrm{e}$ & $\sigma_{\mathrm{GXE}}^{2}$ & $\sigma_{G}^{2}$ & $\sigma^{2} p$ & $\mathbf{h}^{2} \mathrm{bs}(\%)$ & Criteria \\
\hline Plant height $(\mathrm{cm})$ & 13.800 & 25.667 & 16.000 & 26.089 & 61.329 & High \\
\hline Dichotomous height (cm) & 8.518 & 7.478 & 7.323 & 10.762 & 68.044 & High \\
\hline Stem diameter $(\mathrm{cm})$ & 0.006 & 0.014 & 0.003 & 0.008 & 35.876 & Moderate \\
\hline Leaf width $(\mathrm{cm})$ & 0.550 & 0.250 & 0.042 & 0.187 & 22.683 & Moderate \\
\hline Leaf length $(\mathrm{cm})$ & 2.335 & 0.881 & 0.590 & 1.143 & 51.628 & High \\
\hline Day to flowering (days) & 3.480 & 4.217 & 2.290 & 4.082 & 56.097 & High \\
\hline Day to harvest (days) & 17.080 & 45.247 & 12.223 & 29.203 & 41.856 & Moderate \\
\hline Fruit length $(\mathrm{cm})$ & 0.063 & 0.277 & 0.185 & 0.284 & 65.060 & High \\
\hline Fruit diameter (mm) & 0.009 & 0.009 & 0.009 & 0.013 & 70.334 & High \\
\hline Fruit weight $(\mathrm{g})$ & 0.019 & 0.160 & 0.129 & 0.185 & 69.974 & High \\
\hline Number of fruit per plant & 400.576 & 7828.293 & 1269.789 & 3923.728 & 32.362 & Moderate \\
\hline Fruit yield per plant $(\mathrm{g})$ & 712.850 & 6998.717 & 2324.794 & 4736.906 & 49.078 & Moderate \\
\hline
\end{tabular}

Note: $\sigma^{2}$ G: genetic variance; $\sigma^{2}$ GXE: genetic x environment variance; $\sigma^{2} \mathrm{e}$ : environment variance; $\sigma^{2} \mathrm{P}$ : phenotypic variance; $\mathrm{h}^{2} \mathrm{bs}$ : broadsense heritability

Selection will be effective if the additive effects are sufficiently higher than the environmental effect, seen from the high genetic coefficient of variation and also high heritability. From the work of Shabanimofrad et al. (2013), high genetic variation and heritability alone provide no indication of the amount of genetic improvement that would result from selection. The information combined from both of these two parameters is more powerful. In this study, all the traits had moderate (stem diameter, leaf width, day to harvest, number of fruits per plant, and fruit yield per plant) to high (plant height, dichotomous height, leaf length, day to flowering, fruit length and diameter, and fruit weight). From the study done by Belay et al. (2020) dan Rosmaina et al. (2016) this high heritability indicating that the traits were more influenced by genetic factors. Generally, characters like fruit length, fruit diameter, and fruit weight with high genetic variation and heritability should be considered as reliable selection criteria for yield improvement in chili pepper. This result is in an agreement with the work of Usman et al. (2014) that study for heat tolerance chili pepper cultivar.

\section{ACKNOWLEDGEMENTS}

The authors would like to acknowledge the Indonesia Directorate General of Higher Education (DIKTI) for financial support (under PMDSU Research Grant financial year 2020 No. 200/SP2H/PMDSU/DRPM/2020). The author also would thank all parties who helped in data collection and work on this research.

\section{REFERENCES}

Belay F, Abate B, Tsehaye Y. 2020. Genetic variability and characters association of hot pepper (Capsicum annиum L.) genotypes tested under irrigation in Northern Ethiopia. Agric Sci 2 (1): 289-303. 
Cabral NSS, Medeitos AM, Neves LG, Sudre CP, Pimenta S, Coelho VJ, Serafim ME, Rodrigues R. 2017. Genotype x environment interaction on experimental hybrids of chili pepper. Genet Mol Res 16 (2). DOI: 10.4238/gmr16029551.

Ganefianti DW, Suryati D, Hasannudin. 2009. Stability analysis of six chilli pepper populations using additive main effect multiplicative interaction. (AMMI) Agrosia 12 (2): 147-154.

Hu X, Yan S, Shen K. 2013. Heterogeneity of error variance and influence on genotype comparison in multi-location trials. Field Crops Res 149: 322-328. DOI: 10.1016/j.fcr.2013.05.011.

IPGRI, AVRDC, CATIE. 1995. Descriptors for Capsicum (Capsicum spp.). International Plant Genetic Resources Institute, Rome, Italy; the Asian Vegetable Research and Development Center, Taipei, Taiwan, and the Centro Agronómico Tropical de Investigación y Enseñanza, Turrialba, Costa Rica.

Kandel M, Ghimire SK, Ojha BR, Shrestha J. 2017. Analysis of genetic diversity among the maize inbred lines (Zea mays L.) under heat stress conditions. J Maize Res Dev 3 (1): 86-97.

Madu EA, Uguru MI. 2006. Inter-relation of growth and disease expression in pepper using principal component analysis (PCA). Afr J Biotechnol 5 (11): 1054-1057.

McIntosh MS. 1983. Analysis of combined experiments. Agronomy J 75 : 153-155.

Nsabiyera V, Logose M, Ochwo-Ssemakula M, Sseruwagi P, Gibson P, Ojiewo C. 2012. Morphological characterization of local and exotic hot pepper (Capsicum annuum L.) collections in Uganda. Bioremed Biodiver Bioavail 7 (1): 22-32.

Pimenta S, Menezes D, Neder DG, Melo RA, Araujo ALR, Maranhão EAA. 2016. Adaptability and stability of pepper hybrids under conventional and organic production systems. Hortic Bras 34: 168 174. DOI: $10.1590 / \mathrm{S} 0102-053620160000200004$

Rosmaina S, Hasrol FY, Juliyanti, Zulfahmi. 2016. Estimation of variability, heritability and genetic advance among local chili pepper genotypes cultivated in peatlands. Bulgarian J Agric Sci 22 (3): 431436.
Roy D. 2000. Plant Breeding, Analysis and Exploitation of Variation. Narosa Publishing House, New Delhi.

Shabanimofrad M, Rafii MY, Wahab PEM, Biabani AR, Latif MA. 2013. Phenotypic, genotypic, and genetic divergence found in 48 newly collected Malaysian accessions of (Jatropha curcas L.). Ind Crops Prod 42 (1): 543-551. DOI: 10.1016/j.indcrop.2012.06.023

Sharma VK, Senwal CS, Uniyal SP. 2010. Genetic variability and character association analysis in bell pepper (Capsicum апnиит L.). J Hortic For 2 (3): 58-65.

Syukur M, Sujiprihati S, Yunianti S. 2015. Teknik Pemuliaan Tanaman. Penebar Swadaya. Bogor.

Syukur M, Sujiprihati, S, Yunianti R, Kusumah DA. 2010. Evaluasi daya hasil cabai hibrida dan daya adaptasinya di empat lokasi dalam dua tahun. Jurnal Agronomi Indonesia 38 (1): 43-51.

Thul ST, Lal RK, Shasany AK, Darokar MP, Gupta AK, Gupta MM, Verma RK, Kahja SPS. 2009. Estimation of phenotypic divergence in a collection of Capsicum spesies for yield-related traits. Euphytica 168: 189-196. DOI: 10.1007/s10681-009-9882-y

Usman MG, Rafii MY, Ismail MR, Malek MA, Latif MA. 2014. Heritability and genetic advance among chili pepper genotypes for heat tolerance and morphophysiological characteristics. Scientific WorldJournal 2014: 308042. DOI: 10.1155/2014/308042

Votava Baral JB, Bosland PW. 2005. Genetic diversity of chile (Capsicum annuиm var annuum L.) landraces from Northern New Mexico, Colorado, and Mexico. Econ Bot 59: 8-17. DOI: 10.1663/00130001(2005)059[0008:GDOCCA]2.0.CO;2

Wattimena GA, Nurhajati AM, Wiendi NM, Purwito A, Efendi D, Purwoko BS, Khumaida N. 2011. Bioteknologi dalam Pemuliaan Tanaman. Pendahuluan. IPB Press, Bogor.

Whirter KS. 1979. Breeding of Cross-pollinated Crops. In: Knight. R. (Ed). A. Course Manual in Plant Breeding. Australian VideChancellor's Committee, Brisbane.

Wubs AM, Heuvelink E, Marcelis LFM, Hemerik L. 2011. Quantifying abortion rates of reproductive organs and effects of contributing factors using time to event analysis. Funct Plant Biol 38 (5): 431-440. DOI: $10.1071 / \mathrm{FP} 10249$. 